Jesús M. Pérez • Francisco J. González •

Emmanuel Serrano · José E. Granados •

Paulino Fandos · Francisco Carro · Ramón C. Soriguer

\title{
Is blood collected from shot lberian ibex (Capra pyrenaica) useful for monitoring their physiological status?
}

\begin{abstract}
Blood samples were analysed from 175 shot Iberian ibexes, and good-quality samples were obtained in more than $56 \%$ of cases. Sixty-eight of these samples from healthy animals were then used to characterize standard values for the species. Values for 10 blood parameters [monocytes, cholesterol, creatinine, albumin, beta-globulin, gamma-globulin, albumin/globulin $(\mathrm{A} / \mathrm{G})$ ratio, calcium $(\mathrm{Ca})$, phosphates and iron $(\mathrm{Fe})]$ from shot ibexes did not differ from those obtained from healthy captured and physically restrained animals. Blood samples from mange-infested ibexes $(n=31)$ were also analysed and showed higher values for eosinophils and gamma-globulin than samples from healthy animals, but lower values for cholesterol, direct bilirubin, albumin, alpha-2-globulins and chloride. Values from blood parameters can provide useful information about the health and nutritional status of animals, and blood values may thus provide a complementary source of information for animals shot in Andalusia that will prove to be useful for monitoring the physiological status of ibex populations. The protocol described here provides guide-
\end{abstract}

\author{
J. M. Pérez $(\bowtie) \cdot$ E. Serrano \\ Departamento de Biología Animal, \\ Biología Vegetal y Ecología, Universidad de Jaén, \\ Paraje Las Lagunillas, s.n., \\ 23071 Jaén, Spain \\ e-mail: jperez@ujaen.es \\ Tel.: +34-953-212520 \\ Fax: +34-953-211873 \\ F. J. González \\ Laboratorio Prolab, \\ Carrera, 51, Martos, \\ 23600 Jaén, Spain \\ J. E. Granados \\ Parque Nacional de Sierra Nevada, \\ Carretera Antigua de Sierra Nevada, \\ Km. 7, Pinos Genil, \\ 18071 Granada, Spain \\ P. Fandos - F. Carro $\cdot$ R. C. Soriguer \\ Estación Biológica de Doñana (C.S.I.C.), \\ Avenida María Luisa, s.n., Pabellón del Perú, \\ 41013 Sevilla, Spain
}

lines for quick sample collection after an animal's death and standardized instructions for sample storage, transport and analysis.

Keywords Ibex - Bovidae - Ungulates - Management · Haematology $\cdot$ Serum biochemistry

\section{Introduction}

Iberian ibex (Capra pyrenaica Schinz, 1838) is a big game species and a valuable and renewable natural resource. The continuous gathering of information about wild populations is fundamentally important in adaptive management decision-making (Walters 1986; Williams 1996) and for monitoring a wide variety of demographic, physiological, biometrical, behavioural and genetic parameters. To achieve these goals, it is necessary to combine field and laboratory techniques involving the observation, capture, handling and marking of animals with the extraction and analysis of biological samples.

Peinado et al. (1993) studied the influence capture methods have on haematological values in Capra pyrenaica. The effects of captivity on ibex blood composition were also examined by Peinado et al. (1995). Lavín et al. 1997 characterized the haematological values of two ibexes suffering from acute haemonchosis. Pérez et al.1999 gave haematological values for the Sierra Nevada ibex population (southern Spain) and looked for changes provoked by sarcoptic mange infection. More recently, Pérez et al. 2003 characterized the standard values for the haematological and biochemical parameters of this ibex population.

In Andalusia (southern Spain), nearly 700 ibexes are culled every year. These animals are a valuable source of biological tissues and samples that can be used for monitoring a wide range of parameters in a number of different populations. The aim of our study was to determine if analysing blood samples taken from selectively shot animals is a useful means of characterizing certain haematological and biochemical parameters by comparing these values with the reference values for the species. As a secondary 
goal, we compared profiles from healthy animals and ibexes suffering from sarcoptic mange to search for parameters that might serve as indicators for this disease.

\section{Materials and methods}

A total of 175 samples ( 73 from females and 102 from males) were obtained during year-round sampling between 1995 and 1998. The animals ranged from less than 1 year to more than 14 years of age. Animal age was assessed by tooth replacement and horn segment counts (Fandos 1991). Animals were selectively culled as part of a regional plan for managing ibex densities and controlling the spread of sarcoptic mange. Samples came mainly from the Sierra Nevada $(85 \%)$ and other mountainous areas in Andalusia: Málaga (8.1\%), Almería (3.2\%), Jaén (2.3\%) and Cádiz $(1.7 \%)$. Around $4 \mathrm{ml}$ of blood was collected from the heart cavities of shot animals, within $2-10$ min of collapsing. The blood was then transferred into a tube containing the anticoagulant ethylenediaminotetraacetic acid and transported to the laboratory at $4^{\circ} \mathrm{C}$, where it was analysed, normally within 12 and $24 \mathrm{~h}$ after collection. Another sample (4 ml) was transferred into a tube without anticoagulant to be centrifuged in order to obtain serum in the laboratory. Thirteen cytohaematologic [red blood cells (RBC), haematocrit, packed cell volume (PCV), haemoglobin, mean corpuscular volume $(\mathrm{MCV})$, mean corpuscular haemoglobin $(\mathrm{MCH})$, mean corpuscular haemoglobin concentration (MCHC), leucocytes, bands, neutrophils, lymphocytes, monocytes and eosinophils] and 29 biochemical determinations [glucose, cholesterol, triglycerides, uric acid, blood urea, creatinine, aspartate aminotransferase (AST), alanine aminotransferase (ALT), lactate dehydrogenase (LDH), creatine kinase (CK), total bilirubin (TBIL), direct bilirubin
(DBIL), glutamyl transferases (GGT), amylase (AMY), alkaline phosphatase (ALP), proteins, albumin, alpha-1, alpha-2, beta, gamma, albumin/globulin $(\mathrm{A} / \mathrm{G})$ ratio, calcium $(\mathrm{Ca})$, phosphates, iron $(\mathrm{Fe})$, chloride, magnesium $(\mathrm{Mg})$, sodium $(\mathrm{Na})$ and potassium $(\mathrm{K})]$ were carried out as described by Pérez et al. (2003).

Data from samples showing evident haemolysis (reddish discolouration), coagulation (also determined by direct observation), contamination with soil, hair, vegetation and/ or gastrointestinal content (diagnosed by analysing a stained blood sample through a microscope), lipemia (assessed by the direct observation of turbid serum) and those coming from animals suffering from sarcoptic mange were excluded for descriptive purposes. Mange was initially diagnosed by visual inspection, and diagnoses were confirmed subsequently in the laboratory by stereomicroscopic observation of mites in skin samples (three to five pieces of $6.25 \mathrm{~cm}^{2}$ ) digested in $5 \% \mathrm{KOH}$ solution. The remaining values (from apparently healthy animals) were compared with the reference data for the species (Pérez et al. 2003) using the program SPSS 12.0 (SPSS Inc. 2003) by means of Mann-Whitney's test if values differed from a normal distribution (Shapiro-Wilk test) or by Student's test if they fitted the normal distribution. Outliers and extreme values were identified in an exploratory data analysis. A data point is deemed to be an outlier if its point value $>\mathrm{UBV}+$ o.c. $\times$ (UBV-LBV) or data point value $<\mathrm{LBV}-$ o.c. $\times(\mathrm{UBV}-$ LBV), where UBV is the upper value of the box in the box plot (the 75th percentile), LBV is the lower value of the box in the box plot (the 25th percentile) and o.c. is the outlier coefficient (1.5, by default). A data point is deemed to be an extreme value if the following conditions hold: data point value $>\mathrm{UBV}+2 \times$ o.c. $\times(\mathrm{UBV}-\mathrm{LBV})$ or data point value $<\mathrm{LBV}-2 \times$ o.c. $\times(\mathrm{UBV}-\mathrm{LBV})$. When characterizing haematological and biochemical values of culled ibex, the

Table 1 Haematological parameters from healthy ibex shot

\begin{tabular}{|c|c|c|c|c|c|c|c|c|c|c|}
\hline Parameter & Number & Mean \pm SD & Range & $90 \% \mathrm{CI}$ & Reference values & $90 \% \mathrm{CI}$ & SW & $p$ & $\mathrm{MW} / \mathrm{S}$ & $p$ \\
\hline Haematocrit calculated $(\%)$ & 42 & $26.4 \pm 9.2$ & $9.0-44.0$ & $24.0-28.8$ & $46.4 \pm 7.4$ & $45.6-47.3$ & 0.968 & 0.285 & & \\
\hline Haemoglobin $(\mathrm{g} / \mathrm{dl})$ & 40 & $10.3 \pm 3.4$ & $3.7-16.5$ & $9.4-11.1$ & $15.8 \pm 2.3$ & $15.6-16.1$ & 0.971 & 0.377 & & \\
\hline MCHC (\%) & 38 & $37.9 \pm 3.3$ & $31.0-48.5$ & $37.0-38.8$ & $34.0 \pm 3.9$ & $33.6-34.5$ & 0.962 & 0.215 & & \\
\hline Leukocytes $(/ \mathrm{ml})$ & 41 & $6.8 \pm 4.3$ & $0.9-14.4$ & $5.6-7.9$ & $15.5 \pm 6.8$ & $14.7-16.2$ & 0.922 & 0.008 & & \\
\hline Bands $(\%)$ & 36 & $0.8 \pm 1.5$ & $0.0-5.0$ & $0.3-1.2$ & $2.5 \pm 2.7$ & $2.2-2.8$ & 0.574 & 0.000 & & \\
\hline Neutrophils (\%) & 36 & $27.9 \pm 12.9$ & $6.0-61.0$ & $24.3-31.5$ & $38.2 \pm 14.3$ & $36.6-39.8$ & 0.955 & 0.154 & & \\
\hline Lymphocytes (\%) & 36 & $69.5 \pm 14.2$ & $34.0-94.0$ & $65.5-73.5$ & $55.2 \pm 14.7$ & $53.5-56.8$ & 0.959 & 0.196 & & \\
\hline
\end{tabular}

Reference values from Pérez et al. (2003)

$C I$ Confidence interval, $R B C$ red blood cells, $M C V$ mean corpuscular volume, $M C H$ mean corpuscular haemoglobin, $M C H C$ mean corpuscular haemoglobin concentration, $S W$ Shapiro-Wilk test value, $M W / S$ Mann-Whitney's $U / S t$ dent's $t$ value for those parameters not differing from reference values of the species 
90th percentile was chosen as a confidence level because certain parameters showed great biological and analytical variation (Solberg 1999). Finally, values obtained from healthy and mange-infected ibexes were also compared by means of the Mann-Whitney's test. The significance level was set to $\alpha=0.05$.

Table 2 Biochemical values for healthy ibex shot

\begin{tabular}{|c|c|c|c|c|c|c|c|c|c|c|}
\hline Parameter & Number & Mean \pm SD & Range & $90 \% \mathrm{CI}$ & $\begin{array}{l}\text { Reference } \\
\text { values }\end{array}$ & $90 \% \mathrm{CI}$ & SW & $p$ & $\mathrm{MW} / \mathrm{S}$ & $p$ \\
\hline $\begin{array}{r}\text { Glucose } \\
(\mathrm{mg} / \mathrm{dl})\end{array}$ & 49 & $107.0 \pm 114.3$ & $5.4-486.0$ & $79.6-134.4$ & $126.1 \pm 66.0$ & $118.6-133.6$ & 0.807 & 0.000 & & \\
\hline $\begin{array}{l}\text { Cholesterol } \\
(\mathrm{mg} / \mathrm{dl})\end{array}$ & 50 & $49.7 \pm 21.6$ & $25.0-141.0$ & $44.6-54.8$ & $53.0 \pm 21.8$ & $50.5-55.4$ & 0.725 & 0.000 & $4,628.5$ & 0.164 \\
\hline $\begin{array}{l}\text { Uric acid } \\
(\mathrm{mg} / \mathrm{dl})\end{array}$ & 42 & $1.3 \pm 2.4$ & $0.0-13.2$ & $0.7-2.0$ & $0.4 \pm 1.2$ & $0.2-0.5$ & 0.522 & 0.000 & & \\
\hline $\begin{array}{l}\text { Blood urea } \\
(\mathrm{mg} / \mathrm{dl})\end{array}$ & 51 & $49.8 \pm 17.2$ & $20.0-115.0$ & $45.8-53.8$ & $44.4 \pm 15.5$ & $42.6-46.1$ & 0.932 & 0.006 & & \\
\hline $\begin{array}{l}\text { Creatinine } \\
(\mathrm{mg} / \mathrm{dl})\end{array}$ & 51 & $1.8 \pm 0.8$ & $0.6-4.9$ & $1.7-2.0$ & $1.7 \pm 0.7$ & $1.6-1.7$ & 0.862 & 0.000 & $5,014.0$ & 0.342 \\
\hline CK (IU/l) & 49 & $1,789.4 \pm 1,338.4$ & $13.0-4,279.0$ & $1,468.8-2,110.1$ & $748.0 \pm 944.5$ & $638.7-857.3$ & 0.925 & 0.004 & & \\
\hline $\begin{array}{l}\text { TBIL } \\
(\mathrm{mg} / \mathrm{dl})\end{array}$ & 26 & $0.2 \pm 0.3$ & $0.1-1.5$ & $0.1-0.3$ & $0.5 \pm 0.6$ & $0.4-0.6$ & 0.501 & 0.000 & & \\
\hline $\begin{array}{l}\text { DBIL } \\
(\mathrm{mg} / \mathrm{dl})\end{array}$ & 16 & $0.1 \pm 0.1$ & $0.00-0.4$ & $0.1-0.2$ & $0.2 \pm 0.2$ & $0.2-0.3$ & 0.867 & 0.025 & & \\
\hline GGT (IU/l) & 37 & $46.4 \pm 27.8$ & $5.8-140.0$ & $38.7-54.1$ & $51.0 \pm 25.3$ & $48.1-53.8$ & 0.786 & 0.000 & & \\
\hline AMY (IU/1) & 10 & $1,377.6 \pm 763.7$ & $80.5-2,310.0$ & $934.9-1,820.2$ & $482.8 \pm 739.5$ & $356.8-608.9$ & 0.941 & 0.559 & & \\
\hline ALP (IU/l) & 38 & $881.6 \pm 655.9$ & $185.0-2,736.0$ & $702.1-1,061.1$ & $588.1 \pm 528.9$ & $527.9-648.2$ & 0.863 & 0.000 & & \\
\hline $\begin{array}{l}\text { Proteins } \\
(\mathrm{g} / \mathrm{dl})\end{array}$ & 56 & $6.8 \pm 1.5$ & $5.3-14.5$ & $6.4-7.1$ & $7.2 \pm 1.1$ & $7.1-7.3$ & 0.653 & 0.000 & & \\
\hline $\begin{array}{l}\text { Gamma } \\
(\mathrm{g} / \mathrm{dl})\end{array}$ & 55 & $26.2 \pm 7.1$ & $15.3-50.2$ & $24.6-27.8$ & $26.9 \pm 7.7$ & $26.1-27.8$ & 0.903 & 0.000 & $5,013.0$ & 0.067 \\
\hline $\begin{array}{l}\text { A/G ratio } \\
(\mathrm{g} / \mathrm{dl})\end{array}$ & 55 & $1.0 \pm 0.2$ & $0.3-1.5$ & $0.9-1.0$ & $0.9 \pm 0.3$ & $0.9-1.0$ & 0.986 & 0.774 & 1.516 & 0.057 \\
\hline $\mathrm{Ca}(\mathrm{mg} / \mathrm{dl})$ & 50 & $10.7 \pm 1.8$ & $6.9-17.2$ & $10.3-11.2$ & $10.6 \pm 2.0$ & $10.3-10.8$ & 0.958 & 0.075 & 0.698 & 0.486 \\
\hline $\begin{array}{l}\text { Phosphates } \\
(\mathrm{mg} / \mathrm{dl})\end{array}$ & 42 & $8.9 \pm 8.4$ & $4.7-38.5$ & $6.7-11.1$ & $6.9 \pm 2.8$ & $6.6-7.3$ & 0.533 & 0.000 & $3,647.5$ & 0.895 \\
\hline $\mathrm{Fe}(\mathrm{mg} / \mathrm{dl})$ & 36 & $185.5 \pm 80.0$ & $59.3-400.9$ & $162.9-208.0$ & $161.2 \pm 64.8$ & $153.7-168.8$ & 0.919 & 0.011 & $2,918.5$ & 0.071 \\
\hline $\begin{array}{l}\text { Chloride } \\
(\mathrm{g} / \mathrm{dl})\end{array}$ & 50 & $104.0 \pm 11.7$ & $81.0-140.0$ & $101.3-106.8$ & $97.4 \pm 14.9$ & $95.7-99.1$ & 0.957 & 0.068 & & \\
\hline $\mathrm{Mg}(\mathrm{mg} / \mathrm{dl})$ & 49 & $4.2 \pm 1.1$ & $2.1-7.5$ & $4.0-4.5$ & $3.0 \pm 0.8$ & $2.9-3.1$ & 0.956 & 0.063 & & \\
\hline $\mathrm{Na}(\mathrm{mg} / \mathrm{dl})$ & 24 & $138.6 \pm 8.2$ & $118.4-148.5$ & $135.8-141.5$ & $145.2 \pm 8.2$ & $144.0-146.3$ & 0.918 & 0.052 & & \\
\hline $\mathrm{K}(\mathrm{mg} / \mathrm{dl})$ & 24 & $15.4 \pm 8.1$ & $6.6-33.9$ & $12.6-18.3$ & $7.0 \pm 2.6$ & $6.7-7.4$ & 0.873 & 0.0 & & \\
\hline
\end{tabular}

Reference values from Pérez et al. 2003

$C I$ confidence interval, $A S T$ aspartate aminotransferase, $A L T$ alanine aminotransferase, $L D H$ lactate dehydrogenase, $C K$ creatine kinase, $T B I L$ total bilirubin, $D B I L$ direct bilirubin, $G G T$ glutamyl transferases, $A M Y$ amylase, $A L P$ alkaline phosphatase, $S W$ Shapiro-Wilk test value, $M W / S$ Mann-Whitney's $U / S t u d e n t$ 's $t$ value for those parameters not differing from reference values of the species 
Table 3 Haematological parameters from mange-infested ibex shot

$C I$ Confidence interval, $R B C$ red blood cells, $M C V$ mean corpuscular volume, $\mathrm{MCH}$ mean corpuscular haemoglobin, $M C H C$ mean corpuscular haemoglobin concentration

\begin{tabular}{lcccc}
\hline Parameter & Number & Mean \pm SD & \multicolumn{1}{c}{ Range } & $90 \%$ CI \\
\hline RBC $\left(10^{12} / \mathrm{l}\right)$ & 23 & $8.9 \pm 2.6$ & $3.5-13.1$ & $8.0-9.8$ \\
Haematocrit calculated (\%) & 22 & $23.9 \pm 7.1$ & $10.0-34.0$ & $21.2-26.5$ \\
Haematocrit (\%; packed cell volume) & 23 & $24.4 \pm 7.6$ & $9.0-38.0$ & $21.7-27.1$ \\
Haemoglobin (g/dl) & 23 & $9.4 \pm 2.6$ & $3.9-13.5$ & $8.5-10.4$ \\
MCV (fl) & 23 & $27.2 \pm 1.5$ & $24.6-30.0$ & $26.7-27.7$ \\
MCH (pg) & 23 & $10.7 \pm 1.1$ & $8.7-12.3$ & $10.3-11.1$ \\
MCHC (\%) & 23 & $39.3 \pm 3.9$ & $32.1-46.8$ & $37.9-40.7$ \\
Leukocytes (/ml) & 23 & $7.2 \pm 6.1$ & $1.1-23.2$ & $5.0-9.3$ \\
Bands (\%) & 22 & $0.9 \pm 1.5$ & $0.0-5.0$ & $0.4-1.5$ \\
Neutrophils (\%) & 22 & $35.0 \pm 15.5$ & $4.0-59.0$ & $29.3-40.6$ \\
Lymphocytes (\%) & 22 & $62.0 \pm 15.5$ & $35.0-93.0$ & $56.3-67.7$ \\
Monocytes (\%) & 22 & $0.2 \pm 0.5$ & $0.0-2.0$ & $0.0-0.4$ \\
Eosinophils (\%) & 22 & $1.9 \pm 2.1$ & $0.0-7.0$ & $1.1-2.6$ \\
\hline
\end{tabular}

\section{Results}

Of the samples analysed $(n=175), 99(56.6 \%)$ were deemed to be of sufficient quality for use in this study. Thirty-one of these samples came from mange-infected ibexes, the remaining samples $(n=68)$ were used to determine the haematological and biochemical profiles of shot animals (Tables 1 and 2). After eliminating outliers and extreme values, we finally used a variable number of samples for the characterization of values for each parameter. Samples that were excluded from the study either showed evident haemolysis $(61.8 \%)$, contamination (mainly by fungi, $10.5 \%$ ), coagulation $(9.2 \%)$, both coagulation and haemolysis $(7.9 \%)$ or lipemia $(7.9 \%)$; the remaining $2.6 \%$ of samples arrived too late at the laboratory.
Table 4 Biochemical values for mange-infested ibex shot
$C I$ Confidence interval, $A S T$ aspartate aminotransferase, $A L T$ alanine aminotransferase, $L D H$ lactate dehydrogenase, $C K$ creatine kinase, TBIL total bilirubin, $D B I L$ direct bilirubin, $G G T$ glutamyl transferases, $A M Y$ amylase, $A L P$ alkaline phosphatase

\begin{tabular}{|c|c|c|c|c|}
\hline Parameter & Number & Mean \pm SD & Range & $90 \% \mathrm{CI}$ \\
\hline Glucose (mg/dl) & 18 & $110.8 \pm 131.4$ & $1.6-489.0$ & $57.0-164.7$ \\
\hline Cholesterol (mg/dl) & 21 & $39.4 \pm 10.9$ & $23.0-66.0$ & $35.3-43.5$ \\
\hline Triglycerides (mg/dl) & 18 & $85.9 \pm 74.5$ & $10.0-312.0$ & $55.4-116.5$ \\
\hline Uric acid (mg/dl) & 17 & $0.7 \pm 0.7$ & $0.0-2.5$ & $0.4-1.0$ \\
\hline Blood urea $(\mathrm{mg} / \mathrm{dl})$ & 21 & $50.8 \pm 19.0$ & $25.0-108.0$ & $43.6-57.9$ \\
\hline Creatinine (mg/dl) & 21 & $1.6 \pm 0.4$ & $0.9-2.4$ & $1.4-1.7$ \\
\hline AST (IU/l) & 17 & $570.3 \pm 434.6$ & $58.0-1,625.0$ & $386.3-754.3$ \\
\hline ALT (IU/l) & 18 & $83.8 \pm 65.6$ & $16.6-248.0$ & $56.9-110.7$ \\
\hline LDH (IU/1) & 22 & $2,264.0 \pm 1,366.7$ & $82.0-5,057.0$ & $1,762.6-2,765.3$ \\
\hline CK (IU/l) & 16 & $1,424.7 \pm 1,375.1$ & $14.0-3,195.0$ & $822.0-2,027.4$ \\
\hline TBIL (mg/dl) & 12 & $0.4 \pm 0.7$ & $0.1-2.6$ & $0.02-0.7$ \\
\hline DBIL (mg/dl) & 16 & $0.05 \pm 0.04$ & $0.00-0.1$ & $0.03-0.07$ \\
\hline GGT (IU/l) & 17 & $46.4 \pm 23.6$ & $17.1-118.0$ & $36.4-56.4$ \\
\hline AMY (IU/1) & 7 & $781.3 \pm 945.3$ & $40.2-2,610.0$ & $87.0-1,475.6$ \\
\hline ALP (IU/l) & 18 & $679.8 \pm 669.2$ & $212.0-2,618.0$ & $405.4-954.2$ \\
\hline Proteins (g/dl) & 23 & $7.2 \pm 1.4$ & $5.8-11.3$ & $6.7-7.7$ \\
\hline Albumin $(\mathrm{g} / \mathrm{dl})$ & 23 & $41.6 \pm 10.7$ & $17.0-57.1$ & $37.8-45.5$ \\
\hline Alpha-1 (g/dl) & 23 & $6.6 \pm 1.5$ & $4.0-10.0$ & $6.0-7.1$ \\
\hline Alpha-2 (g/dl) & 23 & $10.1 \pm 5.0$ & $1.6-18.9$ & $8.3-11.9$ \\
\hline Beta $(\mathrm{g} / \mathrm{dl})$ & 22 & $7.3 \pm 4.0$ & $2.0-19.6$ & $5.8-8.8$ \\
\hline Gamma (g/dl) & 23 & $34.6 \pm 13.4$ & $18.8-72.0$ & $29.8-39.4$ \\
\hline $\mathrm{A} / \mathrm{G}$ ratio $(\mathrm{g} / \mathrm{dl})$ & 22 & $1.0 \pm 0.4$ & $0.6-2.6$ & $0.8-1.1$ \\
\hline $\mathrm{Ca}(\mathrm{mg} / \mathrm{dl})$ & 17 & $10.6 \pm 2.1$ & $7.3-16.5$ & $9.7-11.5$ \\
\hline Phosphates (mg/dl) & 17 & $9.0 \pm 4.8$ & $5.0-17.0$ & $6.9-11.0$ \\
\hline $\mathrm{Fe}(\mathrm{mg} / \mathrm{dl})$ & 14 & $146.5 \pm 48.8$ & $47.0-215.0$ & $123.4-169.6$ \\
\hline Chloride (g/dl) & 18 & $97.5 \pm 10.6$ & $74.0-115.0$ & $93.2-101.8$ \\
\hline $\mathrm{Mg}(\mathrm{mg} / \mathrm{dl})$ & 16 & $3.8 \pm 1.2$ & $1.6-5.8$ & $3.3-4.3$ \\
\hline $\mathrm{Na}(\mathrm{mg} / \mathrm{dl})$ & 13 & $138.4 \pm 8.1$ & $113.1-145.2$ & $134.4-142.4$ \\
\hline $\mathrm{K}(\mathrm{mg} / \mathrm{dl})$ & 13 & $13.8 \pm 5.0$ & $7.8-27.8$ & $11.3-16.3$ \\
\hline
\end{tabular}


Values for most of the parameters studied differed significantly from the reference values for the species, although those for monocytes, cholesterol, creatinine, albumin, beta- and gamma-globulins, $\mathrm{Ca}$, phosphates and $\mathrm{Fe}$ showed no significant differences from the reference values (Tables 1 and 2). Differences were nearly significant for gamma-globulin, $\mathrm{A} / \mathrm{G}$ ratio and $\mathrm{Fe}$.

Mange-infested ibexes showed higher values of eosinophils and gamma-globulin than healthy ibexes (MannWhitney's $U=269.5, p=0.024)$ and lower values for cholesterol, direct bilirubin, albumin, alpha-2-globulin and chloride ( $p<0.05$; Tables 3 and 4$)$.

\section{Discussion}

Samples used to characterize blood and serum profiles for shot animals were obtained relatively shortly after death (not more than $10 \mathrm{~min}$ ). Transportation conditions to the laboratory, the time elapsed until samples were processed, the methodology of the analyses employed and the laboratory at which they were carried out were all more or less comparable. The samples used to characterize the physiological profiles of shot ibex came from animals belonging to the same population as those which provided the reference values for the Iberian ibex (Sierra Nevada mountain range, southern Spain; Pérez et al. 2003).

After being hit by a bullet, animals may experience stress (fear and pain) and may continue running for a considerable distance (Poljičak-Milas et al. 2004). These factors may explain certain differences in haematological and biochemical profiles between live and shot ibexes, although we unfortunately lack data to fully discuss these differences.

Cell lysis would be evident as values for RBC, haematocrit and the number of leucocytes in shot animals are significantly lower than reference values taken from physically restrained animals. Nevertheless, stress can become higher in physically restrained than in cleanly shot animals, and this would explain the increased haematocrit in the manually restrained animals (Bacon et al. 2005). A similar mechanism may operate on leucocytes (Chapple et al. 1991) and produce stress-induced leucocytosis. Values for MCV, $\mathrm{MCH}$ and $\mathrm{MCHC}$ reflect the above-mentioned changes because they are calculated on the basis of RBC and haematocrit values. Glucose levels of shot animals were significantly lower than those obtained for restrained animals, and this also supports the theory that a clean shot is less stressful than physical restraint. Immobilization stress in desert sheep and goats may result in significantly increased glucose levels (Al-Qarawi 2005). Moreover, successive serial blood sampling of unsedated chital deer (Axis axis) revealed a decrease in values for certain parameters (e.g. erythrocytes, muscle enzymes, glucose and cortisol) with time, which may reflect a reduction in restraint-provoked stress and excitement (Chapple et al. 1991). On the other hand, triglyceride values for shot animals were higher than those obtained for restrained ibexes. If this fact is related to the action of certain hormones such as epinefrin and glucagon (among others) that increase and promote lipid catabolism under stressful conditions and mobilize these macromolecules to blood (Bondi 1989), then the abovementioned theory is contradicted. Triglycerides are usually considered as indicators of good nutrition and can be significantly affected by environmental temperature, time between death and blood taken and time before serum freezing. Other factors, such as fasting or pregnancy, are also important (Sartorelli et al. 1997). Unfortunately, available data do not allow us to explain properly these differences. Another change observed in profiles from culled ibexes was an increase in nitrogen components such as uric acid and urea (Table 2). This is probably due to the degradation of muscular tissues, which leads to an increase in nitrogen molecules (mainly amino acids) in blood. These are then transformed into uric acid and, finally, into urea. Proteins decrease in culled animals, and this may be explained by the mobilization of fibrinogen and other proteinic factors involved in coagulation processes. Enzymes are increased after death, and this could be a sign of hypoxic tissue damage. $\mathrm{Na}$ values decrease but $\mathrm{K}$ values increase after death as a clear sign of $\mathrm{Na}-\mathrm{K}$ pump failure.

Timisjarvi (1981) noted a marked eosinophilia in older reindeer (Rangifer tarandus) and calves during autumn and in females in spring and suggested that this was attributable to parasitic infections. Eosinophilia was one of the main haematological changes noted by Losson et al. (1988) in cattle exposed to the sheep scab mite (Psoroptes ovis). With regard to live ibex, Pérez et al. 1999 found that live mangeinfested ibex had a higher number of eosinophils than healthy ones, although this difference was not statistically significant. Moreover, treated animals that recovered from the disease had significantly lower numbers of eosinophils. This finding is consistent with the fact that these cells are directly involved in immunological responses to allergic and parasitic processes such as sarcoptic mange. It is also coherent that mange-infected animals show higher values of gamma-globulin (IgG), and these two parameters (number of eosinophils and level of gamma-globulin) may be particularly useful for diagnosing the disease. The remaining differences shown by shot mange-infested ibex were consistent with a general catabolic process. At the moment, these profiles agree with visual diagnoses of mange, although further research is still needed to know how the intensity of parasitation (i.e. the number of mites) affects the blood composition. This would be particularly useful in those cases in which diagnosis is difficult, that is, when the infection is so recent that no symptoms have yet developed and the probability to take mites in a skin sample is very low, or when the host has recovered naturally from the disease but still shows visible symptoms such as alopecia.

Blood parameters are influenced by factors such as sex, age and season and/or their interactions (Franzmann 1972). This fact could, at least in part, influence results when we compare heterogeneous groups of animals. It is possible that certain differences found between live and shot ibexes reflect such influence. However, our data did not allow us to address this question.

Values for monocytes, cholesterol, creatinine, albumin, beta- and gamma-globulins, $\mathrm{A} / \mathrm{G}$ ratio, $\mathrm{Ca}$, phosphates and 
Fe from shot animals did not show significant differences from the reference values (Tables 1 and 2) and therefore may provide useful information about the physiological status of shot animals. Given that differences found between shot and physically restrained animals were nearly significant for gamma-globulin, $\mathrm{A} / \mathrm{G}$ ratio and $\mathrm{Fe}$, these parameters might not be comparable between shot and physically restrained animals.

When evaluating condition of Alaskan moose (Alces alces), Franzmann and LeResche (1978) considered PCV, haemoglobin, $\mathrm{Ca}, \mathrm{P}$ and total proteins as the most useful blood parameters for comparing populations because they are not influenced by factors such as excitability, pregnancy and lactation. As $\mathrm{Ca}$ and $\mathrm{P}$ values did not differ between the shot and the restrained animals, these values could therefore be used to monitor the physiological status of shot ibexes.

Beta- (IgA and IgM) and gamma- (IgG) globulins are peptidic molecules involved in immune response. These parameters are therefore related to pathological conditions such as parasitic infections. Concentrations of albumin and globulins were found to be the most sensitive physiological indices in white-tailed deer (Odocoileus virginianus) herd density (Sams et al. 1998). A/G ratio reflects relative change in albumin and total globulin fractions and is therefore depressed when protein malnutrition and starvation occur. This ratio was also extremely responsive to differing densities in white-tailed deer (Sams et al. 1998). It may rise in cases of infection or other disorders when an adequate protein intake occurs (LeResche et al. 1974). Results obtained in our study show that albumin levels from shot and restrained ibexes were comparable, and therefore, albumin values from shot animals could be used to assess their physiological status.

The production of creatinine is related to muscular mass and is a useful index of food intake, the catabolism of body proteins, renal function, hydration level and even of stress (Koch et al. 1987; Delgiudice et al. 1990; Säkkinen et al. 1999). Serum creatinine level was considered to be one of the best variables for evaluating the condition of red deer (Cervus elaphus; Wolkers et al. 1994) and also differs significantly in white-tailed deer density (Sams et al. 1998). As creatinine values from shot and restrained animals were comparable, creatinine levels in blood from shot animals may be useful for monitoring their physiological status.

On average, we estimated that every year, 690 ibexes are shot in Andalusia (southern Spain), 140 on public and 550 on private land. This numbers include both trophy hunting and the selective hunting of the remaining sex and age classes to balance population densities. The price of shooting an ibex ranges from $€ 9.02$ (females) to $€ 2,400$ (trophies), with a mean value of around $€ 900$. The cost of analyses is around $€ 45$ (approximately $5 \%$ ), and we believe that this cost could be easily covered by public game agencies, local government or hunters. If we assume that only $50 \%$ of samples provide good-quality values for the selected parameters and take into account the fact that blood samples collected by hunters would be much less successful, we believe that blood profiles of shot ibexes could be an interesting complementary source of information for use in the management of ibex populations.

Acknowledgements Authors wish to thank the staff of the Sierra Nevada Natural Park for their help in fieldwork, especially to M.C. Pérez, A. Rodríguez, J. García and J. Navarro. This work was supported by an agreement between the Ministry of the Environment of the Andalusian Government (Consejería de Medio Ambiente de la Junta de Andalucía) and the University of Jaén. The research plan 'Plan Andaluz de Investigación' (Junta de Andalucía; RNM-118) partially supports the authors' activities. We also acknowledge the comments of two anonymous referees, which improved greatly our original manuscript. The authors declare that all the fieldwork, sampling and analyses carried out for this study comply with the current Spanish law.

\section{References}

Al-Qarawi AA (2005) Immobilization (restraint) stress in desert sheep and goats, and the influence of pretreatment with xylazine or sodium betaine thereon. Pol J Vet Sci 8:73-78

Bacon SL, Ring C, Hee FLS, Lip GYH, Blann AD, Lavoie KL, Carroll D (2005) Hemodynamic, hemostatic, and endothelial reactions to psychological and physical stress in coronary artery disease patients. Biol Psychol (in press)

Bondi AA (1989) Nutrición animal. Editorial Acribia, Zaragoza

Chapple RS, English AW, Mulley RC, Lepherd EE (1991) Haematology and serum biochemistry of captive unsedated chital deer (Axis axis) in Australia. J Wildl Dis 27:396-406

Delgiudice GD, Mech LD, Seal US (1990) Effects of winter undernutrition on body composition and physiological profiles of white-tailed deer. J Wildl Manage 54:539-550

Fandos P (1991) La cabra montés (Capra pyrenaica) en el Parque Natural de las Sierras de Cazorla, Segura y Las Villas. ICONACSIC, Madrid

Franzmann AW (1972) Environmental sources of variation of bighorn sheep physiologic values. J Wildl Manage 36:924-932

Franzmann AW, LeResche RE (1978) Alaskan moose blood studies with emphasis on condition evaluation. J Wildl Manage 42:334-351

Koch MD, Jessup DA, Clark RK, Franti CE (1987) Effects of capture on biological parameters in free-ranging bighorn sheep (Ovis canadensis): evaluation of dropnet, drive-net, chemical immobilization and the net-gun. J Wildl Dis 23:641-651

Lavín S, Marco I, Rossi L, Meneguz PG, Viñas L (1997) Haemonchosis in Spanish ibex. J Wildl Dis 33:656-659

LeResche RE, Seal US, Karns PD, Franzmann AW (1974) A review of blood chemistry of moose and other cervidae with emphasis on nutritional assessment. Nat Can 101:263-290

Losson B, Detry-Popuplard M, Pouplard L (1988) Haematological and immunological response of unrestrained cattle to Psoroptes ovis, the sheep scab mite. Res Vet Sci 44:197-201

Marco I, Lavín S (1999) Effect of the method of capture on the haematology and blood chemistry of red deer (Cervus elaphus). Res Vet Sci 66:81-84

Peinado VI, Fernández A, Viscor G, Palomeque J (1993) Haematology of Spanish ibex (Capra pyrenaica hispanica) restrained by physical or chemical means. Vet Rec 1993:580 583

Peinado VI, Fernández A, Zabala JLG, Palomeque J (1995) Effect of captivity on the blood composition of Spanish ibex (Capra pyrenaica hispanica). Vet Rec 1995:588-591

Pérez JM, Granados JE, González FJ, Ruiz-Martínez I, Soriguer RC (1999) Hematologic parameters of the Spanish ibex (Capra pyrenaica). J Zoo Wildl Med 30:550-554

Pérez JM, González FJ, Granados JE, Pérez MC, Fandos P, Soriguer RC, Serrano E (2003) Hematologic and biochemical reference intervals for Spanish ibex. J Wildl Dis 39:209-215 
Poljičak-Milas N, Slavica A, Janicki Z, Robić M, Milinković-Tur S (2004) Serum biochemical values in fallow deer (Dama dama L) from different habitats in Croatia. Eur J Wildl Res 50:7-12

Säkkinen H, Timisjärvi J, Eloranta E, Heiskari U, Nieminen M, Puukka M (1999) Nutrition-induced changes in blood chemical parameters of pregnant reindeer hinds (Rangifer tarandus tarandus). Small Rumin Res 32:211-221

Sams MG, Lochmiller RL, Qualls CW Jr, Leslie DM Jr (1998) Sensitivity of condition indices to changing density in a whitetailed deer population. J Wildl Dis 34:110-125

Sartorelli P, Agnes F, Lanfranchi P (1997) Pathophysiological significance of hematochemical parameters of Capra ibex. Hystrix 9:39-44

Solberg EM (1999) Chemometrics, statistical treatment of reference intervals. In: Burtiss CA, Ashwood ER (eds) Tietz textbook of clinical chemistry, 3rd edn. Saunders, Philadelphia, pp 336-356
SPSS Inc (2003) SPSS 12.0 for Windows. SPSS, Chicago

Timisjarvi J (1981) Hematological values for reindeer. J Wild Manage 45:976-981

Walters CJ (1986) Adaptive management of renewable resources. Macmillan, New York

Wesson JA III, Scanlon PF, Kirkpatrick RL, Mosby HS (1979) Influence of the time of sampling after death on blood measurements of the white-tailed deer. Can J Zool 57:777-780

Williams BK (1996) Adaptive optimization and the harvest of biological populations. Math Biosci 136:1-20

Wolkers J, Wensing T, Schonewille JT (1994) Effect of undernutrition on haematological and serum biochemical characteristics in red deer (Cervus elaphus). Can J Zool 72:1291-1296 